\title{
REFORM OF REGULATORY POLICY IN THE FIELD OF SUPERVISION OF AUDIT ACTIVITY
}

\author{
Iryna Kantsir', Marija Plekan² \\ Lviv Polytechnic National University, Ukraine
}

\begin{abstract}
Reforming the regulatory system and supervision of audit activity in Ukraine is a basic condition for Ukraine's accession to the European Community, and the introduction of international standards in the field of audit and supervision of audit activity and quality assurance of audit services should be correlated with the standards of European and world audit practice. The dominant factor in the effective functioning of independent control is the choice of a model of supervision of the mechanism for its implementation; effectiveness of the system of monitoring the quality of audit services; effectiveness of legal and regulatory framework of audit activity. The regulation of audit activity is to coordinate direct and indirect actions aimed at the subject of audit activity with the purpose of ensuring the quality of audit services and minimizing the level of audit risk. The purpose of the research is: analysis of the basic models of regulation of audit activity aimed at improving the legal regulation of economic relations in general and subjects of audit activity in particular. Determination of expediency of implementation of public oversight as monitoring of the process of implementation of audit activity in the context of granting the right to conduct audit activities to individuals, implementation of standards of professional ethics and quality control of audit services, permanence of education and imposing sanctions for non-compliance by auditors with the requirements of the current legislation. Method (methodology). In the process of research, general scientific and special methods of scientific knowledge are used: abstract-logical (in the disclosure of theoretical and methodological foundations of public oversight); synthesis and system analysis (substantiation of the essential characteristics of the system of public oversight); system analysis and theoretical generalization (definition of institutional prerequisites for the introduction of public regulation in audit activity); logical generalization (to substantiate approaches and proposals on improving the ways for ensuring the quality of audit and optimizing the implementation process of the public oversight body). Results. According to the results of the study, an attempt is made to present the author's understanding of the definition of "state regulation" and "public oversight" in the context of the functioning of subjects of audit activities. The expediency of adjusting the vector of regulatory policy regarding the implementation of international standards in the field of audit and supervision of audit activities and quality assurance of audit services is determined. Ways and directions for the implementation of the public supervision body in the audit system of Ukraine are outlined. Improvement of the financing model of the public oversight body with the purpose of minimization of corruption levers of influence is proposed. Practical implications. Taking into account the results of the study, it is proposed to provide in the Budget Code of Ukraine and the Law of Ukraine "On State Budget for the Current Year" a separate article on the costs of partial financing of the Public Audit Oversight Board. This, a priori, will reduce the corruption component of its activities and, accordingly, minimize corruption risks. Value/originality. For the first time, it is proposed to change the structural component of the financing model of the Public Audit Oversight Board and the relevant legislative proposals on clarifying and adjusting the statutes of the current legislation of Ukraine.
\end{abstract}

Key words: audit activities, state regulation, public oversight, stability, systemic risks.

JEL Classification: M40, M42, M48

\footnotetext{
Corresponding author:

${ }^{1}$ Department of Theoretical and Applied Economics, Lviv Polytechnic National University.

E-mail: kanthir02@ukr.net

${ }^{2}$ Department of Accounting and Analysis, Lviv Polytechnic National University.

E-mail: marysiaplekan@gmail.com
} 


\section{Introduction}

In today's conditions of Ukraine's integration into the global financial space, the reform of the audit system is one of the urgent needs. Unification and standardization of the methodology for providing audit services will facilitate the entrance of Ukrainian audit entities to the global audit market and increase the level of their competitiveness.

A prerequisite for changes in the audit field is the study of foreign practices in regulating audit activity in leading countries.

In different countries of the world, its own system of organization and regulation of audit activity is introduced, but its professional regulation and principles of conduct are the same in the vast majority of market economies.

The regulation of audit activity is to coordinate direct and indirect actions aimed at the subject of audit activity with the purpose of ensuring the quality of audit services and minimizing the level of audit risk.

One of the most significant problems of the present is the identification of features of the audit regulation since the functioning of the audit activity on the basis of Ukrainian self-regulation is not sufficiently effective. Domestic auditing firms work only in the state field and have no access to the international audit market.

\section{Models of regulation of audit activity}

The specifics of the organization of audit activity in different countries are manifested in the degree of power interference and control over the operation of auditors (Bondar, 2016).

On the basis of content analysis conducted, three basic models of audit activity regulation are outlined:

1) state regulation;

2) self-regulation;

3) public oversight.

State regulatory policy in the field of economic activity - direction of state policy aimed at improving the legal regulation of economic relations, as well as administrative relations between regulators or other state authorities and economic entities, preventing the adoption of economically inappropriate and ineffective regulatory acts, reducing state interference in the activities of business entities, and eliminating obstacles to the development of economic activities carried out within, in the order and in the manner established by the Constitution and laws of Ukraine (Verkhovna Rada of Ukraine, 2003).

In the context of this study, "state regulation of audit activity" is interpreted as a system of measures carried out by the state on behalf of its authorized bodies and officials with a view to purposefully influencing the behaviour of auditors in relation to the systematization of activities, quality assurance and control, and the receipt of scheduled results.
The purpose of state regulation of audit activity is:

1) implementation of the state unified audit policy;

2) protection of interests of participants in the market for audit services;

3) creation of favourable conditions for the development of audit activity;

4) ensuring equal access to the market;

5) the equality of rights of participants in the market for audit services and their observance of requirements of the current legislation;

6) supervision over transparency and openness of activities; promoting integration into the world audit space.

Self-regulation of audit activity - a kind of control, which is aimed at coordinating the activities of professional auditors, monitoring the efficiency and quality of services rendered, and protecting the interests of consumers.

If to adhere to the "letter of the law", in Ukraine audit activity is carried out on the basis of self-regulation, since regulatory functions in the field of the audit are entrusted to the Audit Chamber of Ukraine.

According to requirements of the Law of Ukraine "On Auditing Activity", the Audit Chamber of Ukraine is an independent body; a non-profit organization formed on a parity basis by delegation to its members of auditors and representatives of state bodies (Verkhovna Rada of Ukraine, 1993). However, in our opinion, the selfregulation of the audit is rather dubious, because the presence in the ACU of ten representatives of public authorities, in addition to the auditors' representatives, indicates a mixed model of regulation.

In fact, the domestic audit existed only at the state level, locally from the world community, because Ukraine is not a part of the states whose audit services are recognized on the European market.

The most common type of regulation is the combination of external regulation and self-regulation, driven by the common goals of the state and professional associations regarding the professional activity of accountants and the desire to enhance the efficiency of each regulator. At the same time, both the state and professional associations of accountants develop and implement professional institutes in clearly delineated spheres of activity (Metelycja, 2013).

Taking into account the experience of the USA in the context of ineffectiveness only of the principle of self-regulation of audit activity (financial misuse and unreliability of indicators of corporate financial reporting) and the adoption of the Public Company Accounting Reform and Investor Protection Act of 2002 (Act Sarbanes-Oxley of 2002, SOx) (Spedding, 2009), whose mission is to create an independent body that is currently setting external auditing standards in the USA and regulating public accounting for the Public Company Accounting Oversight Board (PCAOB) (Moeller, 2009) - it is advisable to analyse 
the implementation of public oversight in the realm of Ukrainian audit.

The current focus on introducing public oversight over audit activity has begun as a result of a series of corporate financial reporting scandals in the USA, Europe, and Japan. By 2002, the auditing community in the world was mostly self-regulating. With the adoption of the SarbanesOxley Act at the international level, a unified view has been established that auditors cannot properly be selfregulated over the lack of sufficient incentives for this: a conflict of interest, present in the relationship of "auditorclient"; the quality of audit is not always recognized and not always encouraged by market participants accordingly; the basis of unregulated competition may be the price or willingness to compromise, not the quality of the audit (Dorosh, 2015).

In line with the requirements of the European Union for the protection of investors' rights, Directive 2014/56/ EC identified ways to improve public oversight of auditors and audit firms and outlined their powers with an emphasis on their independence (European Parliament, Council of the European Union, 2014)

Public oversight of audit activity - monitoring of the process of implementation of audit activity in the context of providing individuals with the right to conduct audit activity, implement professional ethics standards and quality control of audit services, the permanence of education and imposing sanctions on non-compliance by auditors with the requirements of the current legislation.

The system of public oversight of audit activities exists in all Member States of the EU but varies among themselves in terms of accountability, funding, numerical composition, and ways of delegating representatives.

Taking, for example, Bulgaria, it is necessary to emphasize the state funding of the public oversight body, the Commission for Public Oversight of Statutory Auditors (CPOSA), which consists of 5 membersrepresentatives (National Assembly of the Republic of Bulgaria, the Minister of Finance; the Bulgarian National Bank; the Financial Supervision Commission; the Institute of Certified Public Accountants of Bulgaria (ICPA)).

The Public Supervision Authority of Estonia is the Supervisory Board of Public Accountants (SBPA), of which 7 members are appointed by agreement with the Ministry of Finance (at this, two of the experts are practitioners), which is also funded at the expense of budgetary funds.

Public Oversight Body (POB) (Finland), which is identical by number with the Estonian Supervisory Board of Public Accountants (SBPA), is coordinated by the government in the context of the appointment of the Chair and Vice-Chair, and operates on a self-financing basis in the form of mandatory annual payments totalling 2,400,000 EUR. In our opinion, such a form of public oversight body is the most acceptable, since there is no direct dependence on government influence by means of budget financing.

The French High Council for Statutory Audit is quantified from 14 people appointed by the government but operates on a self-financing basis.

Having carried out a certain monitoring of ways of delegation of authority to members of public oversight bodies and methods of their financing, it is possible to conclude that, in the vast majority of countries, the powers of members of public oversight bodies are delegated by government agencies, the domination of public funding is observed in the states of Eastern Europe, and self-financing is inherent in the states of Western Europe (Sweden, France, Finland, Germany, the Netherlands).

Directive 2014/56/EC on 16 April 2014 (European Parliament, Council of the European Union, 2014), which amends and supplements Directive 2006/43/EC European Parliament, Council of the European Union, 2006) and Regulation (EU) No 537/2014 (European Parliament, Council of the European Union, 2014) are considered to be the main regulatory legal acts of the European Union governing the conduct of audit activity in the member states of the European Community.

\section{Transformation of Ukrainian legislation}

In Ukraine, audit activity is at the stage of development and reform, since the evolution of audit reaches only 80 years of the last century. During this period, there was a transition from national to international audit standards; the permanent transformation of the current legislation in the context of its unification with the standards of world practice of audit activity is taking place.

In compliance with requirements of the European Union for the implementation of international standards in the field of audit and supervision of audit activity and quality assurance, in Ukraine, the Verkhovna Rada of Ukraine adopted the Law "On Audit of Financial Statements and Audit Activities" on 21 December 2017 and handed over to be signed to the President on 22 January 2018. According to this statutory instrument, the approaches to audit, the principles of regulation and quality assurance of audit services are significantly changed.

In order to comply with the requirements of Directive 2014/56/EC and Regulation (EU) No 537/2014, the definition of "public-interest entities" was introduced into circulation, which defined the enterprises-issuers whose securities are admitted to stock trading, banks, insurers, non-state pension funds, other financial institutions (except other financial institutions and nonstate pension funds belonging to microenterprises and small enterprises) and enterprises belonging to large enterprises (Verkhovna Rada of Ukraine, 1999).

At the request of the EU, the classification of enterprises was launched in Ukraine with their division 
into: microenterprises (book value of assets up to 350 000 euros, sales revenue - up to 700000 euros, average number of employees - 10 people); small enterprises (book value of assets up to 4000000 euros, sales revenue - up to 8000000 euros, average number of employees - up to 50 people); medium enterprises (book value of assets up to 20000000 euros, sales revenue - up to 40000000 euros, average number of employees - up to 250 people); large enterprises (book value of assets over 20000000 euros, sales revenue over 40000000 euros, average number of employees more than 250 people) (Verkhovna Rada of Ukraine, 1999).

\section{Public Audit Oversight Board}

With the change of regulatory policy, it is envisaged to organize public oversight of audit activities, which will be coordinated by the Public Audit Oversight Board. Structurally, the Public Audit Oversight Board is composed of Audit Oversight Council and Quality Assurance Inspection. This regulatory service will function as a non-profit person of public law.

The basic competencies of the Public Audit Oversight Board include:

- supervision of subjects of audit activity;

- monitoring of the implementation of international standards on auditing;

- monitoring of the permanent educational process of auditors who carry out the mandatory audit of financial statements;

- quality control of audit services; coordination of disciplinary proceedings against auditing entities and enforcement of penalties.

The public oversight body actually oversees activities of the Audit Chamber of Ukraine, which, in turn, gains the status of a truly independent regulator, because in contrast to the previous methods of forming its composition (20 people, of which 10 persons are representatives of the audit community, 10 persons representatives of state authorities). In accordance with the requirements of the adopted, but currently dormant, Law "On Audit of Financial Statements and Audit Activities", the total number of members of the Council of the Audit Chamber of Ukraine is 11 personsprofessional auditors whose work experience is at least five years (Verkhovna Rada of Ukraine, 2017).

A feature of the Law of Ukraine "On Audit of Financial Statements and Audit Activities" (Verkhovna Rada of Ukraine, 2017) is a way of financing the Public Audit Oversight Board, according to which, under each agreement for the provision of audit services of mandatory audit of public-interest entities, subjects of audit activity are obliged to pay defined contributions, in particular:

1) fixed contribution in the amount of three minimum wages established by law on 1 January of the reporting year from each audit report prepared by the subject of audit activity based on the results of the provision of audit services for the mandatory audit to the publicinterest entity;

2 ) contribution in the percentage of the remuneration amount under an agreement for the provision of audit services for a mandatory audit to public-interest entities, the size of which is determined by the Cabinet of Ministers of Ukraine.

It is obvious that self-financing reduces the level of government influence, but in the realities of the Ukrainian audit, financing of the Public Audit Oversight Board only by retaining contributions from auditors can lead to an increase in obligations of audit firms, which will result in an increase in the level of corruption risks.

It is advisable to introduce indirect proportional funding to the Public Audit Oversight Board, using the experience of European states.

The experience of Italy, where the financing model of the Public Audit Oversight Board is shaped by the following principles, can be useful:

1) Audit of Non-PIEs General Accounting Office of the State (RGS) carries out public oversight of audit firms that are not of special importance to the state (funded by contributions from participants);

2) Audit of PIEs Italian Securities and Exchange Commission (CONSOB) carries out public oversight of firms conducting an audit of public importance (funding is provided through government grants and contributions from participants of the market for audit services).

In our opinion, it is necessary to modify approaches to the financing policy of the Public Audit Oversight Board, in particular: to introduce indirect proportional funding at the expense of budget funds and contributions of auditors. In particular, financing of the Audit Oversight Council's activities maybe carried out at the expense of the State Budget and obligatory contributions of participants the market for audit services, while the financing of the Quality Assurance Inspection - exclusively at the expense of contributions from auditors.

\section{Findings}

Public oversight is an objective paradigm of audit activity that contributes to the qualitative performance of auditors' tasks in assuring and minimizing the auditor's risk in carrying out audit procedures.

Based on the results of the study of methods of regulating audit activity at the macrolevel, one can conclude that it is expedient to introduce a public oversight institution for the purpose of:

- monitoring of the process of implementation of audit activity in the context, giving individuals the right to conduct audit work;

- implementation of standards of professional ethics and quality control of audit services,

- permanent education; 
- imposing sanctions for auditors' non-compliance with requirements of the current legislation.

The issue of financing the Supervisory Authority is debatable since the goal of transformation of legislation in the field of the audit is its unification with the norms of world practice of audit activity and minimization of corruption risks. We remain in the position that the state represented by representative bodies, coordinates, regulates, and protects interests of society and, therefore, should partly finance supervisory authorities.

\section{Conclusions}

Taking into account the results of the study, it is proposed to provide in the Budget Code of Ukraine and the Law of Ukraine "On State Budget for the Current Year" a separate article on the costs of partial financing of the Public Audit Oversight Board. This, a priori, will reduce the corruption component of its activities and, accordingly, minimize corruption risks.

The proposal regarding such an amendment to the current legislative provision will result in a new wording of paragraph 13, Article 13 of the Law of Ukraine "On Audit of Financial Statements and Audit Activities" (Verkhovna Rada of Ukraine, 2017): "In order to ensure financing of activities of the Public Audit Oversight
Board, under each agreement for the provision of audit services of mandatory audit of public-interest entities, subjects of audit activity are obliged to pay contributions in favour of the Public Audit Oversight Board as follows: 1) fixed contribution in the amount of three minimum wages established by law on 1 January of the reporting year from each audit report prepared by the subject of audit activity based on the results of the provision of audit services for the mandatory audit to the public-interest entity;

2) contribution in percentage of the remuneration amount (excluding value added tax) under agreement for the provision of audit services for mandatory audit to public-interest entities, the size of which is determined by the Cabinet of Ministers of Ukraine based on the estimate of the Public Audit Oversight Board, but cannot exceed two percent of the amount of such remuneration."

The following subparagraph 3 shall be appended to paragraph 13, Article 13 of the Law of Ukraine "On Audit of Financial Statements and Audit Activities": "The state acting by authorized bodies carries out indirect proportional funding of the Public Audit Oversight Board as related to the implementation of state policy in the field of supervision over audit activity in order to provide authority and perform functions by the Audit Oversight Council."

\section{References:}

Bondar, V. P. (2016). Systemy orghanizaciji ta reghuljuvannja audytorsjkoji dijaljnosti krajin svitu [Systems of organization and regulation of audit activity of countries of the world], Mizhnarodnyj zbirnyk naukovykh pracj, vol. 2(11), pp. 5-20.

European Parliament, Council of the European Union (2006). Directive 2006/43/EC of the European Parliament and of the Council of 17 May 2006 on statutory audits of annual accounts and consolidated accounts, amending Council Directives 78/660/EEC and 83/349/EEC and repealing Council Directive 84/253/EEC. Retrieved from: http://eur-lex.europa.eu/eli/dir/2006/43/oj.

European Parliament, Council of the European Union (2014). Directive 2014/56/EU of the European Parliament and of the Council of 16 April 2014 amending Directive 2006/43/EC on statutory audits of annual accounts and consolidated accounts. Retrieved from: http://data.europa.eu/eli/dir/2014/56/oj.

European Parliament, Council of the European Union (2014). Regulation (EU) No 537/2014 of the European Parliament and of the Council of 16 April 2014 on specific requirements regarding statutory audit of publicinterest entities and repealing Commission Decision 2005/909/EC. Retrieved from: http://data.europa.eu/eli/ $\mathrm{reg} / 2014 / 537 / \mathrm{oj}$.

Dorosh, N. (2015). Rozvytok audytorsjkoji dijaljnosti v Ukrajini v umovakh jevrointeghracijnykh procesiv [Development of audit activity in Ukraine in the conditions of euro-integration processes], Bulletin of the Taras Shevchenko National University of Kyiv. economy, 10 (175), pp. 17-23.

Metelitsa, V. M. (2013). Mizhnarodni pidkhody do reghuljuvannja bukhghaltersjkoji profesiji [International approaches to accounting profession management], Oblik i finansy vol. 3 (61), pp. 35-47.

Moeller, Robert R. (2009). Brink's modern internal auditing: a common body of knowledge, John Wiley \& Sons, Inc, p. 794.

Spedding, Linda S. (2009). The Due Diligence handbook: corporate governance, risk management and business planning, CIMA-Elsevier Ltd, Linacre House, Jordan Hill, Oxford, p. 710.

Verkhovna Rada of Ukraine (1993). Pro audytorsjku dijaljnistj [About audit activity]. Retrieved from: http:// zakon4.rada.gov.ua/laws/show/3125-12.

Verkhovna Rada of Ukraine (1999). Pro bukhghaltersjkyj oblik ta finansovu zvitnistj v Ukrajini [On Accounting and Financial Reporting in Ukraine]. Retrieved from: http://zakon5.rada.gov.ua/laws/card/996-14

Verkhovna Rada of Ukraine (2003). Pro zasady derzhavnoji reghuljatornoji polityky u sferi ghospodarsjkoji dijaljnosti [On the Principles of State Regulatory Policy in the Field of Economic Activity]. Retrieved from: http://zakon0.rada.gov.ua/laws/show/1160-15.

Verkhovna Rada of Ukraine (2017). Pro audyt finansovoji zvitnosti ta audytorsjku dijaljnistj [On Audit of Financial Reporting and Auditing]. Retrieved from: w1.c1.rada.gov.ua/pls/zweb2/webproc4_1?pf3511=62776. 